\title{
RELATIONSHIPS BETWEEN THE BROOD STOCKS AGE, SIZES (WEIGHT AND LENGTH) AND FIRST FISH MATURATION FOR BOTH MALES AND FEMALES OF EUROPEAN SEA BASS, Dicentrarchus labrax (L.). Abd El-Hakim, N. F.*; M. S. Hussein*and A. A. H. Shahen ** * Faculty of Agriculture, Al-Azhar University, Nasr City, Cairo, Egypt. ** The General Authority for Fish Resources Development, Nasr City, Cairo, Egypt.
}

\begin{abstract}
The objectives of this study aimed to evaluate the relationships between the brood stocks age, sizes (weight and length) and first fish maturation for both males and females of European sea bass Dicentrarchus labrax (L.).

The present study was carried out in the Marine Fish Hatchery belonging to the General Authority for Fish Resources Development (GAFRD), Ministry of Agriculture and Land Reclamation, ARE. The hatchery located at the $21^{\text {th }} \mathrm{km}$ western of Alexandria at the road from Alexandrian to Matruh governorate. The study was performed during May 2001 to December 2004. For this experiment a total number of 300 of developed sea bass juveniles aging three months were involved. Averages of sea bass weights and lengths at the experimental start were $7.8 \pm 2.6 \mathrm{~g}$ and $4.5 \pm$ $1.2 \mathrm{~cm}$, respectively. The present study aimed to determine the age, weight and length of sea bass $(D$. labraxL.)at first sexual maturity.

The obtained results are summarized in the following:

1. The first mature males $(13.7 \%$ of the fish sample) were detected at 12 months, while in females it was detected at 15 months of age (3.3\% of the sample).

2. Percent of mature males and females in the sample increased in almost linear manner with each advance in age to become fully mature in the sample at 36 months of age with a total weight range of 678.9 to $995.8 \mathrm{~g}$ for males and 853.6 to $1142.3 \mathrm{~g}$ for females.

3. Age appeared significant effects on body weights and lengths in both male and female sea bass where both measurements increased with each advance in age.

4. Starting with the age of 12 months, percent of mature males and females in the sample increased with each advance in age to reach $100 \%$ maturation at 36 months of age.

5. The correlation coefficients calculated between age and each of total body weight, body total length and percent of maturation were significant.

The study clearly indicated that the first mature males $(13.7 \%$ the sample) were detected at 12 months of age with the average of total weight between 109.6-150g and the average of total length between $18.4-21 \mathrm{~cm}$, while in females it was detected at 15 months (3.3\% of the sample) and the average of total weight was $291.2 \mathrm{~g}$, and the average of total length was $33.6 \mathrm{~cm}$. The complete sexual maturity of female occurred at 36 months of age at body weight ranging from 678.9 to $995.8 \mathrm{~g}$ and, which the total length was 38.2 to $60.6 .4 \mathrm{~cm}$, in males at the same age and average body weights ranging from 853.6to $1142.3 \mathrm{~g}$ with the total length was 43.2 to $68.5 \mathrm{~cm}$. The sea bass male and female fish reached $100 \%$ maturation with a sex ratio to $1: 1.1$ for female and male, respectively.
\end{abstract}

Keywords: Brood stocks age, sizes ,first fish maturation, European sea bass , Dicentrarchus labrax (L.). 


\section{INTRODUCTION}

The European sea bass (Dicentrarchus labrax L.) is an important cultured species in the Mediterranean region. The European sea bass is a marine aquaculture species of major economic interest in Europe but it is recognised that the skewed sex-ratio in favour of males observed under culture conditions, and their early maturation compared to females still represent important drawbacks for commercial production (Zanuy et al., 2001). Although significant contributions have already been made in this field, much work is still concerned with sex control methods in this species (Pavlidis et al., 2000; Zanuy et al., 2001and Koumoundourous et al., 2003). Genetic and physiological approaches generally require the set-up of midterm or long-term studies and considerable amount of work in sexing juveniles or adult fish. Sexually mature sea bass can be recognised macroscopically by their gonads according to the classification of Barnabé (1976). The demand and high value of this species led to farm cultivate this fish under extensive condition in Egypt. Aquaculture production reached 80 161 tonnes in 2005 (FEAP, 2006), with Greece producing 35000 tonnes, followed by Turkey (20 $900 \mathrm{t}$ ), Italy $(9,800 \mathrm{t})$, Spain (6 $130 \mathrm{t}$ ), and France (4 $300 \mathrm{t})$.

The successful large-scale cultivation of this species for human consumption demands when the resource be easily renewable. It is clearly disadvantageous to cultivate marine finfishes when the supply of young cannot easily be replenished; yet, the history of aquaculture has been dogged by just this problem. There are two solutions to this problem: the first is eminently practical and has been the historical answer to collect fry from natural resources. Yet, the difficulties inherent in this method are many, for it is time consuming, requires considerable skill and experience and relies utterly on the productivity of the natural spawning grounds. The second solution is more direct: learn how to make the brood stock marine finfishes reproduce in captive. A primary requirement as far as brood stock management and good farming practice are concerned is an ability to control fully the sexual maturation and spawning of the marine finfishes species under cultivation. Without this control farmers have to rely on collections of wild brood stock, larvae or fry in order to complete the cycle of production. European sea bass, D.labrax, like many other teleosts inhabiting temperate latitudes, used seasonal pattern of changing day length modulated by temperate to synchronize their spawning, So that they occur at the most favorable time of the year for survival of offspring (Barnabé,1990). During the first year of life the gonads of european sea bass remain undifferentiated, with sexual differentiation occurring some time after this event (Robin and Brusle, 1983). However, Blazquez et al. (1995) suggested that sex differentiation in captive sea bass may occur at an earlier age of 9 months. They added that, a sensitive period for alteration of ovarian or testicular configuration by steroids hormone administration has been identified between 126 and 226 days post hatching. As regards to sex ratio, Barnabé (1990) reported that a high proportion of males (70-90\%) has been observed in 
several Mediterranean hatcheries, also the possible environmental and or social factors resulting in such unequal sex ratio are not known.

Eggs are produced all year around using adequate temperature and photoperiod. Sea bass spawn naturally in tanks and buoyant eggs are collected at the water outlet of the spawning tanks. In captivity, first sexual maturation occurs in 1-2 years-old males and in 3-5 years-old females. A generation interval of 2 years can be obtained in controlled rearing conditions but in practice it is longer and ranges between 4 and 6 years. Eggs and sperm can be collected by a gentle pressure on the flanks of anaesthetized fish. Hormonal stimulation of ovulation by $\mathrm{LHRH}-\mathrm{a}$ or $\mathrm{GnRH}-\mathrm{a}$ is needed to collect eggs (Zanuy et al.2001). Sperm can be frozen with several types of protocols.

Determination of body length and age at first sexual maturity is the most important parameters to serve as basis for reproduction management of sea bass. Rafail (1971) estimated the length and age at maturity for European sea bass (D.labrax), and showed that the ripe males of this fish first appeared in catch at $19.5 \mathrm{~cm}$ body length and 2 years of age, while ripe females sexual onset appeared at $25 \mathrm{~cm}$, in length and 3 years of age. Brusle and Roblin (1989), reported that under culture conditions, puberty in European sea bass males is reached near the second year of life, depending more on the body size attained on the age of animal. They added that, in contrast, puberty in females usually occurs $2 y e a r s ~ l a t e r$ and these differences in reproduction strategy resulted in a relatively higher growth performance in females than males. The same authors showed also that in captivity, under natural photoperiod and temperature, 2years old immature female sea bass, attain $0.5 \pm 0.04 \mathrm{Kg}$ in weight and $33.7 \pm 0.06 \mathrm{~cm}$, in length, compared with $0.3 \pm 0.02 \mathrm{Kg}$ and $28.5 \pm 0.6 \mathrm{~cm}$ for spermating males of the same age. They also added that during the third year of life, the differences in weight and size between males and females are not as pronounced as in previous year, probably as a result of the maturity of females. They concluded that these facts favour the development of techniques for the monosex (all females) culture of sea bass.

In Egyptian coast of Mediterranean, Wassef and El-Emary (1989) found that onset of spawning of females sea bass occurred at $20 \mathrm{~cm}$ in length (2years) and $29 \mathrm{~cm}$ (4 years) for females. Bou Ain (1977) gave a comparison of length at first maturation of sea bass in some countries on areas of the world.Caporiccio and Connes (1977), Mayer et al, (1988) Zohar (1989), Zohar et al. (1989) and Barnabé (1994) described the cellular types in the gonads and their changes during the sexual cycle in European sea bass D.Labrax. They reported that in sea bass, as in other teleost, gonadal maturation involves many months of preparation, where on the later stages of growth and gamete release are but brief interludes in the development process, i, e. vilellogenesis starts in October and lasts 4-5 months, whereas spawning time in the Mediterranean is restricted to a month in the winter.Alvarino et al. (1992) studied the pattern of sea bass oocyte development after experimental ovarian stimulation. They reported that sea bass show group synchronous oocyte development and have ovaries which contain more-than one group of developing oocytes. Thus, the sea bass in 
culture is a multiple spawner, confirming previous observation of Mayer et al. (1990) for wild stocks.

The present study was performed during 3 years from May 2001 to December 2004 and aimed to determine the relationships between the brood stocks age and sizes (weight and length) and the first fish maturation for both males and females of European sea bass (Dicentmrchus labrax) at first sexual maturity .

\section{MATERIALS AND METHODS}

The present study was conducted in Marine Finfishes Hatchery located at the $21 \mathrm{Km}$. west of Alexanderia. Matruh governorates. The hatchery belongs to the General Authority for Fish Resources Development (GAFRD), Ministry of Agriculture and Land Reclamation, ARE. The present experiment was performed during 3 years from May 2001 to December 2004 and aims to determine the relationships between the brood stocks age, sizes (weight and length) and first fish maturation for both males and females of European sea bass (Dicentmrchus labrax) at first sexual maturity .

\section{Experimental Fish}

A total number of 300 sea bass (Dicentrarchus labrax) developed juveniles (males and females) were used in this experiment ( which were produced from the mating of parent stock of the hatchery) aging three months (average initial weight of $7.8 \pm 1.34 \mathrm{~g}$ and an average initial length of 4.5 $\pm 1.09 \mathrm{~cm}$ ) at experimental start to determine fish age, weight and length at first fish sexual maturity.

\section{Experimental Diets}

During this experiment, the experimental sea bass (Dicentrarchus labrax) developed juveniles (mixed sexes) were daily fed during the first period, from 3 to 9 months of age on minced tilapias flesh at a rate of $12 \%$ of the fish biomass. Whereas from 9 to 12 months of age $\left(2^{\text {nd }}\right.$ period) the experimental diet contained minced tilapias flesh at daily rate of $10 \%$ of biomass (Table 1). During the period 3 from 12 to 15 months, experimental sea bass (Dicentrarchus labrax) developed juvenilesperiod from 12-15 month of age were fed on dry pelleted food $(47.6 \%$ crude protein) at a daily rate of $8 \%$ of biomass, and period 4 from 15- 24 months of age fed the same test diet but at a daily rate of $6 \%$ of total fish biomass.Period 5 from the 24 to 36 months of age the experimental fish were fed on the same diet, but at a daily rate of $3 \%$ of fish biomass (Tables 1 and 2 ).

Table (1): Experimental periods ( lasted for 5 consecutive periods)and feeding regeme

\begin{tabular}{|l|c|c|}
\hline Period & Age & Feed and rate for feeding \\
\hline Period. 1 & From 3-9 month & Minced tilapia $-12 \%$ \\
Period .2 & From 9- 12 month & Minced tilapia $-10 \%$ \\
Period. 3 & From 12-15month & Dry food-8\% \\
Period.4 & From 15-24 month & Dry food-6\% \\
Period. 5 & Form 24-36 month & Dry food-3\% \\
\hline
\end{tabular}


Table (2): Ingredient and proximate composition of the experimental test diet used in feeding sea bass from 12-36 months of age.

\begin{tabular}{|c|c|}
\hline Ingredient & $\%$ \\
\hline Fish meal (FM)* & 68 \\
\hline Rice bran (RB) & 11 \\
\hline Yellow corn flour(YC) & 10 \\
\hline Soybean meal ${ }^{* *}$ & 3 \\
\hline Cotton seed meal (decorticated) & 4 \\
\hline Cod liver oil ${ }^{* \star *}$ & 2 \\
\hline Mineral +Vitamins mixture ${ }^{\star \star \star \star}$ & 2 \\
\hline Total & 100 \\
\hline \multicolumn{2}{|l|}{ Proximate analysis ( \%) } \\
\hline Dry matter (DM) & 88.4 \\
\hline Crude Protein (CP) & 47.6 \\
\hline Total lipids (TL) & 17.2 \\
\hline Ash & 19.5 \\
\hline Crude Fiber(CF) & 1.9 \\
\hline NFE $^{1}$ & 13.8 \\
\hline Gross energy (GE) (kcal//OOg D.M $)^{2}$ & 434.3 \\
\hline
\end{tabular}

* Source from Brazil

** Solvent extracted

*** Cod live oil product by Iceland

**** Each gram of vitamin premix contains (NRC, 1993 ), 20.000IUvit. A2000 IU vit. D3, 400 vit. E, $20 \mathrm{mg}$ Niacin, $4.5 \mathrm{mg}$ riboflavin, $3 \mathrm{mg}$ pyridoxine, $0.0 ! 3 \mathrm{mg}$ vit. B12, $100 \mathrm{mg}$ chorine chloride and $2 \mathrm{mg}$ vit K.Each gram of minerals contains $0.83 \mathrm{Ca}, 0.63 \mathrm{P}, 0.78$ $\mathrm{Na}, 0.018 \mathrm{Mn}, 0.011 \mathrm{Zn}$ and $0.001 \mathrm{Cu}$.The Mixture was prepared by mixing 35parts of dicalcium phosphate, 3 parts of mineral premix and 2 part of common salt.

${ }^{1}$ Calculated by differences

${ }^{2}$ Growth energy was calculated using values of $5.65,4.1$ and $9.45 \mathrm{Kcal} / \mathrm{g}$ protein , carbohydrate and lipid ,respectively (Jobling, 1983) .

\section{Fish rearing facilities}

In the present experiment, sea bass (Dicentrarchus labrax\} developed juveniles (mixed sexes), were stocked in a circular concrete tank with a total sea water volume of $50 \mathrm{~m}^{3}$ till termination of the experiment, i.e three years after start. This water of the experimental tanks was changed completely (daily rate of $100 \%$ ) and the tanks were supplied with continuous air through a blower of $15 \mathrm{hp}$. capacity which provided $15 \mathrm{~m}^{3}$ air per second.In this experiment, all fish were monthly transferred to another clean tank with the same specification to avoid infection with bacteria or parasites.

\section{Sea water supply system:}

Sea water was drawn directly from an intake point in the shore by subs and well point (150 u.m slots, 3pipes PVC, 3m length). Sea water was pumped by $4 \mathrm{~kW}$ polypropylene centrifuge pump to three concrete reservoirs of $60 \mathrm{~m}^{3}$ capacity, $11 \mathrm{~m}$ diameter $\times 1.5 \mathrm{~m}$ depth. The reservoir was used as a setting to the coarser suspended particles before the water was filtered. Water was pumped from reservoir to two constant head tanks ( $5 \mathrm{~m}^{3}$ capacity) to distribute for maturation and spawning tanks, and pumped to larval tanks. Drainage system and air supply system:

All the tank facilities were provided with two drainage system, one for cleaning water and other to remove water used in experimental larval 
rearing. The air supply system consists of three air blowers work alternating at 24-hour interval. The air distribution network was constructed of PVC pipes and control valves.

\section{Measurements and records}

Age of both males and females sea bass was recorded. Total weight and total length of each individual fish were recorded to the nearst $0.1 \mathrm{~g}$ and $1 \mathrm{~mm}$, respectively. Both weight and length of the experimental fish were recorded every 3 months till the end of the third year after experiment start. Age at sexual first maturity was determined by inserting a plastic canula in the urino-genital openning to collect the eggs from the females, while semen was collected from males by stripping on the abdominal area towards tial fin. The collected eggs were examined under a light microscope to measure egg diameter (microne) and the diameter of the oil globuler. Age at first maturation for male and female fish was further recorded

\section{Water quality parameters}

Physical and chemical water parameters in experimental tanks were determined according to Boyd (1990). Water temperature in ${ }^{\circ} \mathrm{C}$ was daily recorded in all experimental tanks using a simple thermometer. Water $\mathrm{pH}$ was measured in the present experiment every week using a digital $\mathrm{PH}$ meter(model up Hep). Dissolved oxygen $\left(\mathrm{mg} \mathrm{O}_{2} / \mathrm{L}\right.$ ) was monitored within all experimental tanks every week using a digital $0_{2}$ meter(YSI model MP57).Water salinity was determined in all experimental tanks al the periods previously mentioned in the experiment using a refractometer(model $\mathrm{U}$ 81150-20).Ammonia(mg NH $\mathrm{NH}_{4}$-N/L)was determined using colormeter(Model $\mathrm{HAC)}$.

\section{Analytical feed methods :}

Feed ingredients and experimental diets were analyzed for proximate composition according to AOAC(1990). Gross energy was estimated using values of $4.15 \mathrm{Kcal} / \mathrm{g}$ carbohydrate, $9.4 \mathrm{Kcal} / \mathrm{g}$ lipid and $5.5 \mathrm{Kcal} / \mathrm{g}$ protein as reported by ( Jobling, 1983) .

\section{Growth performance data}

Fish were counted and batch - weighed at stocking and at harvest. Mortality was monitored daily and survival was defined as the fraction of the stocked fish that were harvested.Average initial(Wi)and final fish body weight $\left(\mathrm{W}_{1}\right)$ were calculated. Rearing time $(\mathrm{t})$ was defined as the period from the first to the last day that the fish were fed.

\section{Statistical analysis}

All data were analyzed statistically using SAS(2005) program. Duncans multiple range test $\{1955)$ was carried out to test the significance among treatments means $(\mathrm{P}<0.05)$.

\section{RESULTS AND DISCUSSION}

Results of Table (3) illustrate the effect of age ,weight and length of sea bass on maturation percentage. At 3 months of age, averages of body weight(BW) of sea bass was found to be $7.8 \pm 2.6 \mathrm{~g}$ with an average length of $4.5 \pm 1.2 \mathrm{~cm}$. At 6 months of age average body weight and body length increased. During ages $9 ; 12 ; 15 ; 18 ; 21 ; 24$ and 36 months of age body 
weight of sea bass increased significantly $(\mathrm{P}<0.05)$ almost in a linear manner with each advance in fish age.

Body length(BL) behaved almost in a similar manner as body weight, thus it increased significantly $(\mathrm{P}<0.05)$ with each advance in ages 21 and 24 months. Results of Table 3 and Fig.(1) indicate that sea bass (male and female), average of BW at the experimental start (3months of age) was $7.8 \pm$ $2.6 \mathrm{~g}$ and it increased in order with each advance in age to reach $913.9 \pm$ $92.5 \mathrm{~g}$ at 36 months, increased its BW by 906.1 folds during the period from the third to the 36 months of age in both sexs. Results of Table (3) and Fig. (1) revealed that during the ages 3 to 36 months of age BW showed a highly significant correlation $(P<0.05) r=0.94$. Also results of the same Table and the Fig. (2) show that the age revealed a positive significant $(P<0.05)$ correlation with fish $\mathrm{BL}(r=0.91)$. Results illustrated in Table (3) and Fig. (3) declared that maturation percentage is highly dependent on age of sea bass with significant $(P<0.05)$ correlation coefficient $(r=0.69)$.

Table (3). Effect of age, body weight and total length on percentage maturation of sea bass in experimental tanks, (mean values $\pm \mathrm{SE}$, ) in period during May 2001 to December 2004.

\begin{tabular}{|l|c|c|c|}
\hline Age Month & $\begin{array}{c}\text { Weight } \\
(\mathbf{g})\end{array}$ & $\begin{array}{c}\text { Length } \\
(\mathbf{c m})\end{array}$ & $\begin{array}{c}\% \\
\text { Mature }\end{array}$ \\
\hline 3 & $7.8^{\mathrm{h}} \pm 2.6$ & $4.5^{\mathrm{h}} \pm 1.2$ & $0^{\mathrm{e}} \pm 0$ \\
\hline 6 & $21.6^{\mathrm{h}} \pm 5.1$ & $9.2^{\mathrm{g}} \pm 1.9$ & $0^{\mathrm{e}} \pm 0$ \\
\hline 9 & $56.4^{\mathrm{g}} \pm 15.17$ & $13.8^{\mathrm{f}} \pm 2.1$ & $0^{\mathrm{e}} \pm 0$ \\
\hline 12 & $110.3^{\dagger} \pm 32.14$ & $18.6^{\mathrm{e}} \pm 1.9$ & $13.7^{\mathrm{de}} \pm 0.35$ \\
\hline 15 & $208.25^{\mathrm{e}} \pm 48.6$ & $26.6^{\mathrm{d}} \pm 4.7$ & $26.6^{\mathrm{cd}} \pm 0.44$ \\
\hline 18 & $241.3^{\mathrm{d}} \pm 44.04$ & $36.5^{\mathrm{C}} \pm 6.6$ & $29.4^{\mathrm{c}} \pm 0.46$ \\
\hline 21 & $311.9^{\mathrm{C}} \pm 63.8$ & $41.2^{\mathrm{b}} \pm 7.9$ & $41.1^{\mathrm{c}} \pm 0.49$ \\
\hline 36 & $346.8^{\mathrm{b}} \pm 66.05$ & $41.8^{\mathrm{b}} \pm 5.4$ & $65.5^{\mathrm{b}} \pm 0.48$ \\
\hline & $913.9^{\mathrm{a}} \pm 92.5$ & $51.3^{\mathrm{a}} \pm 7.5$ & $100^{\mathrm{a}} \pm 0.00$ \\
\hline
\end{tabular}

Values in the same column with different superscripts are significantly different at $\mathbf{P}<0.05$

As presented in Table (3) and Fig.(4) results revealed that maturation percent of both sea bass males and females correlated significantly $(P<0.05)$ with fish weight $(r=0.68)$.

Concerning the relationship between fish length (male and female sea bass) results of Table (3) and Fig .(5) revealed that percent of maturation is significantly $(P<0.05)$ dependent on fish length $(r=0.65)$.From results of Table (3) and Fig (5), it was noticed that both weight and length of sea bass (males + females) are correlated highly $(P<0.05)$ with a correlation coefficient of $(r=0.85$. $)$

Regarding results of Table (4), results revealed that at age 3, 6 and 9 months after hatch no maturation was observed. At 12 months of age, only $13.7 \%$ (males only) showed maturation with length range of $18.4-21 \mathrm{~cm}$ and weight range of $109.6-150.0 \mathrm{~g}$. At 15 months of age, $3.3 \%$ females and $23.3 \%$ of males reached maturation with an average length of $33.6 \mathrm{~cm}$ and weight of $291.2 \mathrm{~g}$. for females and $20.1-27 \mathrm{~cm}$ and $145.2-217.4 \mathrm{~g}$ for males, respectively. At 18 months of age, $8.8 \%$ and $20.5 \%$ of the remain ding 
females and males showed maturation in the sample. At 21 months of age, $14.7 \%$ and $26.4 \%$ of females and males reached maturity in the sample examined. Furthermore at 24 months of age, 27.5 and $38 \%$ of females and males reached maturity in the tested sample, respectively. At the age 36 months, $100 \%$ of fish were mature. In general results of Table (4) show that male of sea bass mature earlier than their female and the maturation percent increased with each advance in age to reach complete maturation (100\%) at 36 months of age. At 36 months, the ratio between matured females to males was determined to be $1: 1.1$.

Results illustrated in Tables 3 and 4 are closely in accordance with those reported by Wassef and El-Emary (1989), they reported that the first appearance of mature sea bass in wild was recorded at $17 \mathrm{~cm}$ length group representing $14.3 \%$ of the males examined. He added that this percent incased in the successive length group $22 \mathrm{~cm}$. i.e male sea bass attain their first sexual maturity with a length ranging between 17 and $22 \mathrm{~cm}$. The same author reported also that females sea bass attain their first sexual maturity at length ranging between 26 and $32 \mathrm{~cm}$. which is in complete agreement with results obtained in the present study (Tables 3 and 4).

Table (4): Effect of age, weight and total length on maturation development of sea bass $D$. labrax in experimental tanks in period during May 2001 to December 2004(mean values \pm SE)

\begin{tabular}{|c|c|c|c|c|c|c|c|c|c|}
\hline \multirow[t]{2}{*}{$\begin{array}{l}\text { Age } \\
\text { month }\end{array}$} & \multirow[t]{2}{*}{$\begin{array}{c}\text { Fish } \\
\text { No. }\end{array}$} & \multirow{2}{*}{\begin{tabular}{|l} 
Total \\
length \\
(cm)
\end{tabular}} & \multirow{2}{*}{\begin{tabular}{|c|} 
Total \\
weight \\
(g)
\end{tabular}} & \multicolumn{2}{|c|}{$\begin{array}{c}\text { Mature } \\
\text { fish }\end{array}$} & \multicolumn{2}{|l|}{ Female } & \multicolumn{2}{|l|}{ Male } \\
\hline & & & & No. & $\%$ & No. & $\%$ & No. & $\%$ \\
\hline 3 & 29 & 4.5 & 7.8 & - & 0 & & 0 & & 0 \\
\hline 6 & 33 & 9.5 & 21.6 & - & 0 & & 0 & & 0 \\
\hline 9 & 31 & 13.8 & 56.4 & - & 0 & & 0 & & 0 \\
\hline 12 & 29 & 18.6 & 110.3 & 4 & 13.7 & - & 0 & 4 & 13.7 \\
\hline length rang & - & - & - & - & & & & 18.4-21 & - \\
\hline weight rang & - & - & - & - & & & & 109.6-150 & \\
\hline 15 & 30 & 26.6 & 208.25 & 8 & 26.6 & 1 & 3.3 & 7 & 23.3 \\
\hline length rang & & & & - & & 33.6 & & 20.1-27 & \\
\hline weight rang & & & & & & 291.2 & & $145.2-217.4$ & \\
\hline 18 & 34 & 36.5 & 241.3 & 10 & 29.3 & 3 & 8.8 & 7 & 20.5 \\
\hline length rang & & & & & & 43.3-48.2 & & $31.4-41.3$ & \\
\hline weight rang & & & & & & $278.6-330.1$ & & $198.1-267.4$ & \\
\hline 21 & 34 & 41.2 & 311.9 & 14 & 41.1 & 5 & 14.7 & 9 & 26.4 \\
\hline $\begin{array}{l}\text { length rang } \\
\text { weight rang }\end{array}$ & & & & & & \begin{tabular}{|c|}
$40.3-60.4$ \\
$331.6-443.4$ \\
\end{tabular} & & $\begin{array}{c}33.4-58.3 \\
241.3-439.8 \\
\end{array}$ & \\
\hline 24 & 29 & 41.8 & 346.8 & 19 & 65.5 & 8 & 27.5 & 11 & 38 \\
\hline $\begin{array}{l}\text { Length rang } \\
\text { weight rang }\end{array}$ & & & & & & \begin{tabular}{|c|}
$41.7-54.3$ \\
$344.1-497.4$ \\
\end{tabular} & & $\begin{array}{c}34.8-49.4 \\
272.5-463.2\end{array}$ & \\
\hline 36 & 36 & 51.3 & 913.9 & 36 & 100 & 17 & 47.2 & 19 & 52.8 \\
\hline length rang & & & & & & $43.2-68.5$ & & $38.2-60.6$ & \\
\hline weight rang & & & & & & $853.6-1142.3$ & & 678.9-995.8 & \\
\hline
\end{tabular}
0.05 
In general, results of the present study may lead us to conclude that length at first maturity is $18.4-21 \mathrm{~cm}$ for males and $24-36 \mathrm{~cm}$ for females of Egyptian sea bass. Also results of the present study are in accordance with the findings of Wassef and El-Emary (1989), who reported that sea bass males attain first maturation at length range $17-22 \mathrm{~cm}$ and females $23-32 \mathrm{~cm}$. Fish bigger than $22 \mathrm{~cm}$ for males and $32 \mathrm{~cm}$ for females were all sexually mature. In this connection, Abdo (1996) reported that females of sea bass smaller then $25 \mathrm{~cm}$ in length were all immature, while all males smaller than $17 \mathrm{~cm}$ were immature which is in complete agreement with the results of the present study (Table 4). The same author showed that the mature individuals appear with small percentage (12.6\%) in females at $25 \mathrm{~cm}$ and inmales at 17 $\mathrm{cm}$. The percentage of mature individuals increased with the successive increase in length to reach $66.67 \%$ at $21 \mathrm{~cm}$ and $30 \mathrm{~cm}$ length for males and female, respectively. She added that at length $31 \mathrm{~cm}$ the mature female increased and sexually mature individuals were about $71.43 \%$ at length 22 $\mathrm{cm}$, i.e. all males larger than $23 \mathrm{~cm}$ in length were sexually mature. In this connection, Brusle and Roblin (1989) and Blazquez et al. (1995) recorded that males of sea bass. D. labrax reached maturity at two years of age. On the other hand, females reach maturity at 3 years. In England, bass reach maturity at $4-6$ years of age $(35-40 \mathrm{~cm}$.) and may continue to spawn for to 20 years Abdo (1996). Mayer et al., (1990) has also observed similar observation. Mediterranean sea bass first reach maturity at smaller size and lower age than Atlantic bass (Barnabé, 1990 and Blazquez et al., 1995).

Concerning the effect of lighting regime, on maturation of male sea bass Rodriguez et al, (2001) exposed groups of 4-month-old sea bass over three consecutive years to a natural photoperiod (40 N)(NP), constant long photoperiod (15L:9D) explain and 18-month-expanded photoperiod (the natural light cycle extended to 18 months) (EX), under natural conditions of temperature $\left(12.0-26.3^{\circ} \mathrm{C}\right)$. They found that during the differentiation period, a significant increase in number of precocious males was found in the LO $(26.8 \%)$ and explain $(17.7 \%)$ groups compared to controls $(5.3 \%)(\mathrm{P}<$ $0.05)$.During the first reproductive season (20-25months of age), gonad size (GSI) in both the explain $(0.82 \pm 0.16 \%)$ and the explain $(0.28 \pm 0.07 \%)$ groups was significantly lower than controls $(1.28 \pm 0.41 \%)$. The same authors showed also that (he percentage of spermiating males during the first reproductive period was lower in explain $(<60 \%)$ and explain $(<35 \%)$ group compared to controls $(>80 \%)$. They added that at the second reproductive period (32-37 months of age), gonadal maturation was advanced in EX group, whereas a significant delay was observed in LO group with respect to control. Spermiation in EX group was advanced with respect to control group. During the second reproductive period, percentage of spermiating males was significantly higher in EX group ( $80 \%$ ) than in LO group (<50\%) LO and EX groups displayed enhanced growth $(655.52 \pm 37.21 \mathrm{~g}$ and $376.40 \pm 6.33$ $\mathrm{mm} ; 510.44 \pm 25.80 \mathrm{~g}$ and $350.14 \pm 5.27 \mathrm{~mm}$, respectively) compared to controls $(459.93 \pm 21.20 \mathrm{~g}$ and $343.62 \pm 4.82 \mathrm{~mm}$ ). They concluded that there is a significant beneficial effect of constant long and expanded photoperiod on reducing sea bass gonadal development and enhancing growth at the age of commercialisation. 
Abd El-Hakim, N. F. et al.

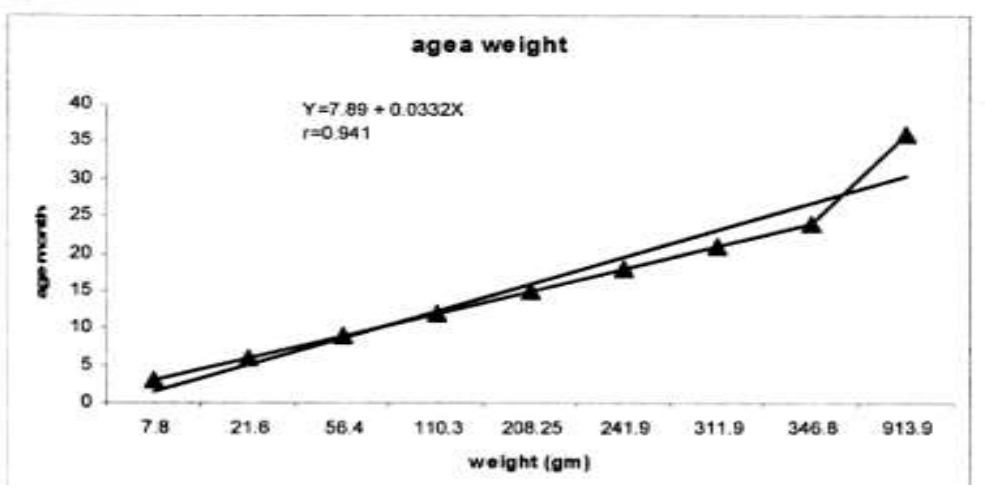

Fig (1). The relation between weight (g) and age (months) of sea bass $D$. labrax

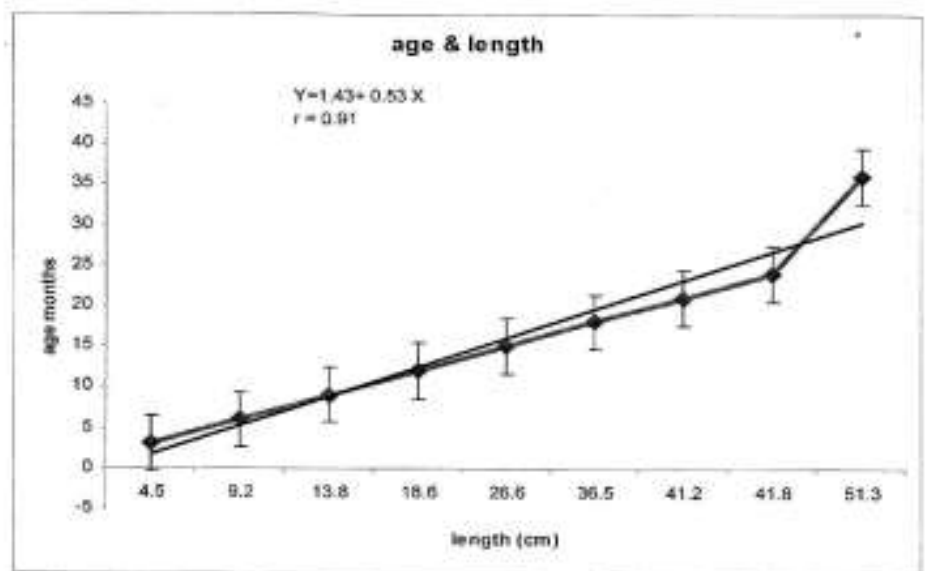

Fig (6). The relation between length ( $\mathrm{cm}$ ) and age (months) of sea bass D.labrax

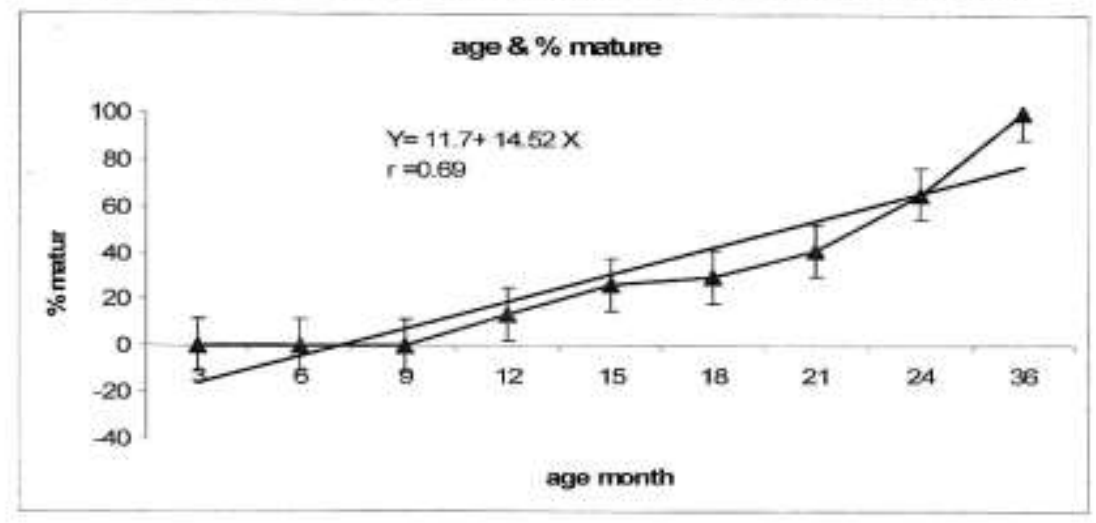

Fig (7). The relation between percentage of maturity and age (months) of sea bass D.labrax 


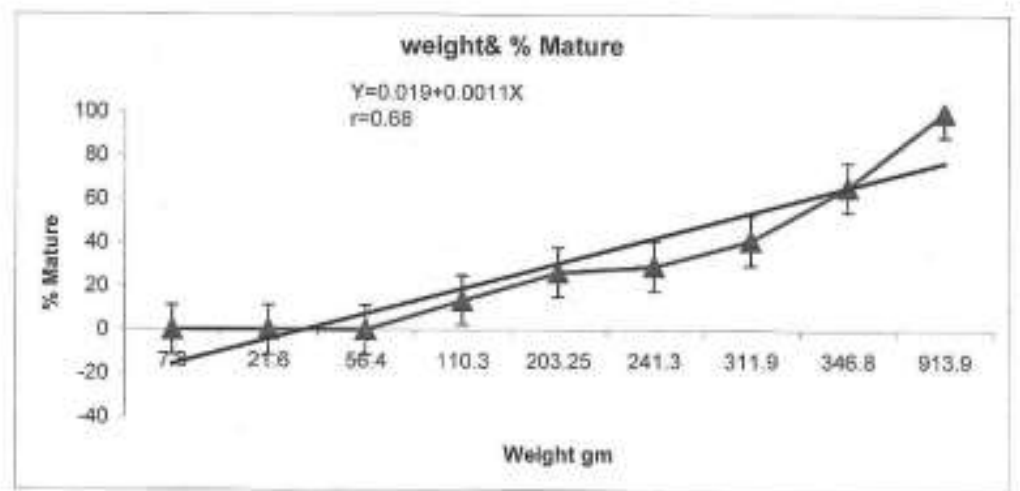

Fig (8). The relution between weight (gm) und percentuge of maturity at sea bass D.labrax

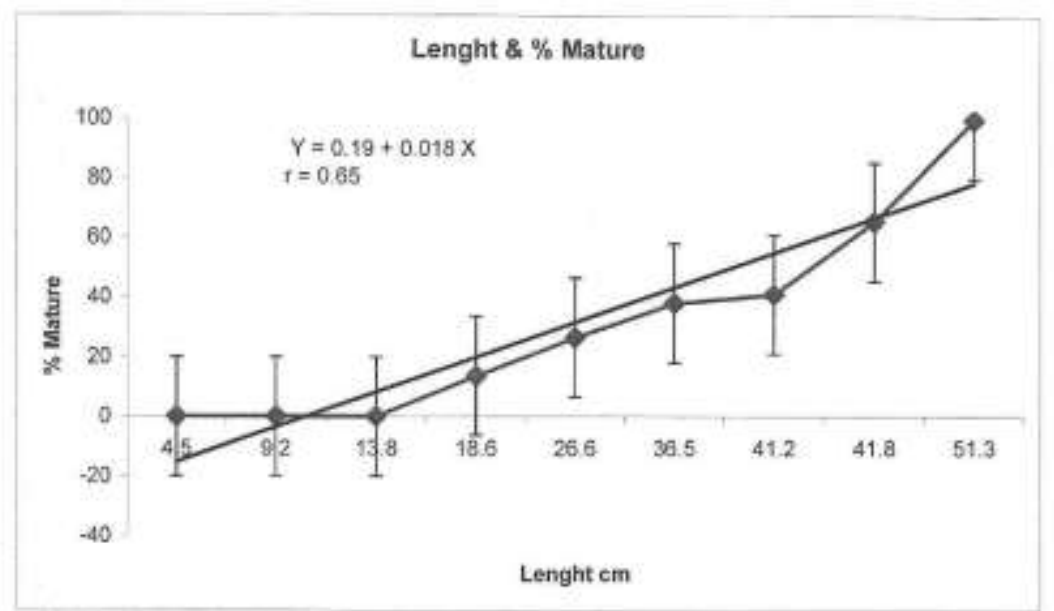

Fig (9). The relation between length ( $\mathrm{cm}$ ) and percentage of maturity on sca bass D.labrax

\section{Physico-chemical characteristics of experimental tanks water :}

Results of Table(5) show the physico-chemical characteristcs of experimental tanks water during 36 successive months from May 2001 to December 2004 during this experiment.Water quality parameters including water temperature $\left({ }^{0} \mathrm{C}\right)$, dissolved oxygen (DO) , $\mathrm{pH}$, ammonia $\left(\mathrm{NH}_{3}-\mathrm{N}\right)$ and salinity (ppt\%o) were measured throughout the experiment. All water quality parameters were within the permissible levels for sea bass aquaculture. The chemical equilibrium between undissociated ammonia and total ammonia is a function of salinity, temperature and, to a large extent, pH (Miller et al., 1990; Soderberg and Meade, 1991 and Boyd, 1990). For equal initial concentration values of total ammonia, a pH variation from 7 to 8 leads to a 10 -fold increase in the formation of the toxic fraction (Lloyd, 1992). 
Table (5): Physical and chemical water parameters in experimental tanks.

\begin{tabular}{|l|c|c|c|}
\hline Parameters & Minimum & Maximum & Mean \pm SE \\
\hline Water temperature $\left({ }^{0} \mathrm{C}\right)$ & 14.4 & 29.4 & $21.9 \pm 7.4$ \\
\hline Dissolved oxygen (DO), mg/l & 6.1 & 6.5 & $6.3 \pm 0.21$ \\
\hline $\mathrm{pH}$ & 7.4 & 8.0 & $7.7 \pm 0.30$ \\
\hline Ammonia $\left(\mathrm{NH}_{4}-\mathrm{N}\right) \quad \mathrm{mg} / \mathrm{l}$ & 0.033 & 0.061 & $0.047 \pm 0.014$ \\
\hline Salinity $(\% \circ)$ & 30.2 & 35.4 & $32.8 \pm 2.6$ \\
\hline
\end{tabular}

\section{REFERENCES}

Abdo A. and Malak A.(1996). Reproductive biology and induced spawning of Dicntrarchus labrax. Ph. D. Nat. Inst. of Oce. And Fish., Alexandria.

Alvarino. J. M. R.., Zanuy, S,Prat,F.,Carrillo,M.and Mananos, E. (1992). Stimulation of ovulation and steroid secretion by LHRH-a injcetion in the sea bass, Dicentrarchus labrax, effect of time of day. Aquaclture, 102: $177-186$.

AOAC(Association of Official Analytical Chemists)(1990). Official methods of analysis of the Association of Official Analysis Chemists, $15^{\text {th }}$ edition AOAC,Inc,Arlington. Virginia,U.S.A.

Barnabé, G. (1976). Contribution à la connaissance de la biologie du loup, $D$. labrax L.(Serranidae) de la région de Sète. Thèse Doct. D'État, Université du Languedoc, 0 Montpellier, 426 pp.

Barnabe, G. (1990) .Rearing bass and gilthcad bream. Aquaculture, 2 (ed G. Barnabe), Ellis Horwood. New York pp 64-86.

Barnabe.G.(1994).Aquaculture.Biology and Ecology of cultured species.Ellis Horwwod,NewYork

Blazquez, M. Piferrer, F., Zanuy, S., Carrilla, M. and Donaldson, E.(1995) Development of sex control techniques for European sea bass $(D$. labrax L.) aquaculture: effect of 17 - methyltestosteron prior to sex differentiation. Aquaculture, 135: 329- 342.

Bou-Ain, A. (1977). Contribution a 1'etude morphologique, anatomique et biologique de (Dicentrarchus labrax) (Linn, 1758) et Dicentrarchus punctatus (Bloch, 1792) des cotes tunisiennes. Thesis, University of Tunis, $115 \mathrm{pp}$.

Boyd, C. E. (1990). Water Quality in ponds for aquaculture. Agriculture Experiment Station, Auburn Univ, Alabama, U.S.A.482 pp.

Brusle, J. and Roblin,C. (1989). Sexualite du loup (Dicentrarchus labrax L.) en condition d'elevage controle .IN; G. Barnabe and R. Billard (Editor). L'Aquacllure du Bar et des Saprides' INFRA publ., Paris, pp. 33- 43.

Caporiccio. B. and Connes. R. (1977). Etude ultrastruclurale des enveloppes pcriovocytaires et periovulaires de Dicentrarchus labrax L. (Poisson Telcosteen). Annales de Science Naturelle. Paris. Zoologie (12 erne Ser.). 19: 351-68.

Duncan,D. B (1955). Multiple range and multiple F- test. Biometrics, range (1): 1-42. FEAP (2006). Aquaculture statistics. www.feap.org 
Jobling.M.,(1983).. A short review and critique of methodology used in fish growth and nutrition studies. J. Fish Biology,23:685 - 703.

Koumoundouros, G., Pavlidis, M., Anezaki, L., Kokkari, C., Sterioti, A., Divanach, P. and Kentouri, M. (2003). Temperature sex determination in the European sea bass, Dicentrarchus labrax (L., 1758) (Teleostei, Perciformes, Moronidae): critical sensitive ontogenetic phase. Journal of Experimental Zoology 292, 573-579.

Lloyd, R. (1992). Pollution and Freshwater Fish. Fishing News Books, West Byfleet.

Mayer, I.. Shackley, S.E. and Ryland, J. S. (1988). Aspects of the reproductive biology of the bass, Dicentrarchus labrax L. I. An histological and histochemical study of oocyte development. J. Fish. Biol. 33: 609- 622.

Mayer, I., Shackley, S.E. and Witthames,P.R.(1990).Aspects of the reproductive biology of the bass, $D$. labrax L.II.Fecundity and pattern of oocyte development.J.Fish. Biol. 36: 141-148.

Miller, C.L., Poucher, S., Cardin, J.A. and Hansen, D.,(1990). The acute and chronic toxicity of ammonia to marine fish and a mysid. Arch. Environ. Contam. Toxicol. 19, 40- 48.

NRC, (1993), Nutrient Requirement of Fish. Committee on Animal Nutrition. Board on Agriculture, National Research Concul. National Academy Press. Washington, D.C.1993

Pavlidis, M., Koumoundouros, G., Somarakis, S., Divanach, P. and Kentouri, M. (2000). Evidence of temperature-dependent sex determination in the the European sea bass (Dicentrarchus labrax L.). Journal of Experimental Zoology 287, 225-232.

Rafail,S.Z.(1971).Investigation on Sciaenidae and Moronidae catches and on the total catch byseine on the U.A.R.Mediterranean cost, stud.Rev..Fish.Conn Medite.,48:1-26.

Roblin, C. and Brusle J. 1983. Ontogenesc gonadopue et differentiation sexuclle du loup $D$. labrax, en conditions d' elevage. Reprod. Nutr. Develop. 23(1): 115-127.

SAS( 2005). Statistical Analysis System, SAS program, ver. 9.1. SAS institute incorporation, Gary, NC 27513 USA.

Soderberg, R.N.and Meade, J.W., (1991). The effects of ionic strength on unionized ammonia concentration. Prog.Fish-Cult. 53: 118- 120.

Wassef, E. and El-Emary, H. E. (1989) Contribution to the biology of bass, $D$. labrax $L$, in the Egyptian Mediterranean waters off Alexandria CYBIUM. 13 (14): 327-345.

Zanuy S., Carillo M., Felip A., Rodriguez L., Blasquez M., Ramos J. and Piferrer F. (2001). Genetic, hormonal and environmental approaches for the control of reproduction in the European sea bass (Dicentrarchus labrax L.). Aquaculture, 202: 187-203.

Zohar, Y., (1989). Endocrinology and fish farming aspects in reproduction growth and somoltification Fish Phys. Biochem., 7: 395-405, 
Zohar,Y., Tosky, M., Pagelson, G. and Finkelman, Y.(1989). Introduction of spawning in the gilthead sea bream, Sparus aurata, using (D-Ala ${ }^{6}$ Pro ${ }^{9}-\mathrm{NET}$ ) LHRH: comparison with the use of HCG. BIBL-CITAT. Israeli Journal of Aquaculture, 41(3): 105-113.

العلاقات بين عمر وحجم (وزن وطول) مخزون ذكور وانـاث سمك القاروص عند

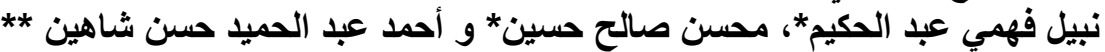

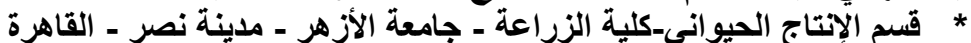
* الهيئة العامة لتنمية الثروة السمكية ـ مدينة نصر - القاهرة

أجريت هذه الدراسة في المفرخ البحري التابع للايئة العامـة لتتمية الثروة السمكية، التابعة لوزارة

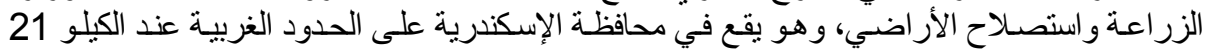

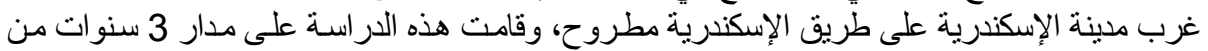

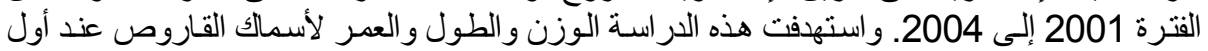

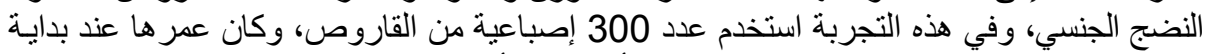

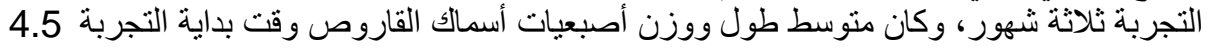
و 1.2

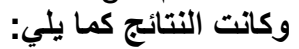

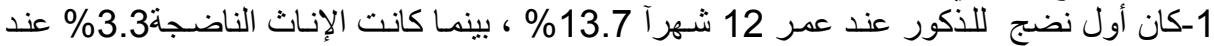

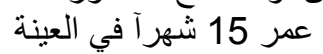

2-ز ادت النسبة المئوية لنضج كلاً من الذكور و الإناث في العينة بأسلوب خطي على التو الي ميع تقدم

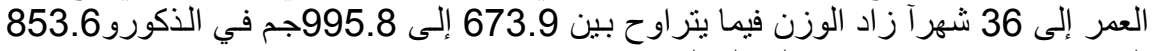

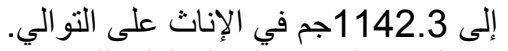

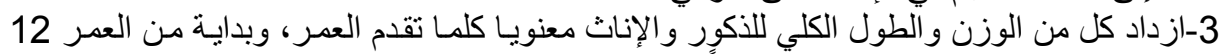

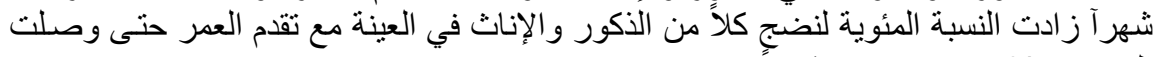
إلى 100\% عند عمر 36 شهراً. 4- معـاملات الإرتباط بين العمر وكـلاً من الوزن و و الطول الكلي و النسبة المئويـة للنضـج كانت

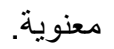

كلية الزراعة - جامعة المنصورة كلية الزراعة - جامعة قناة السويس الصورة
قام بتحكيم البحث

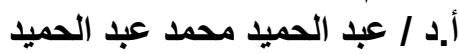

أيد / محمد عبد الحميد الدناصورى اعيد الحميد 